\title{
CONJUNCTIVAL ENDOGENOUS MICROBIOTA IN PATIENTS SUBMITTED TO CATARACT SURGERY
}

\author{
Claudete I. Locatelli ${ }^{1}$, Sérgio Kwitko ${ }^{1}$, Amauri Braga Simonetti ${ }^{2 *}$ \\ ${ }^{1}$ Serviço de Oftalmologia, Hospital de Clínicas de Porto Alegre, Universidade Federal do Rio Grande do Sul, Porto Alegre, RS, \\ Brasil. ' 2 Departamento de Microbiologia, Instituto de Ciências Básicas da Saúde, Universidade Federal do Rio Grande do Sul, \\ Porto Alegre, RS, Brasil.
}

Submitted: July 29, 2002; Returned to Authors: October 17, 2002; Approved: September 08, 2003

\begin{abstract}
Bacterial isolation, identification and antimicrobial susceptibility tests were carried out in ocular material collected with swab and polimethylmethacrylate (PMMA) or silicone intraocular lenses (IOL) from forty six patients submitted to cataract surgery. Seventy six isolates and seven different microorganisms were identified. Coagulase-negative staphylococci (CNS) were the predominant microorganisms isolated from swabs $(71.4 \%$ of cases), PMMA lenses (81.3\%) and silicon lenses (77.8\%). Coagulase-negative staphylococci isolates revealed high resistance to penicillin $\mathrm{G}$ followed by tetracycline, chloramphenicol and aminoglicosides. However, these isolates displayed great susceptibility to vancomycin, cephalothin and ofloxacin. Except for penicillin G, Staphylococcus aureus was very sensitive to the antimicrobial agents including oxacillin. Among Gram-negatives, Proteus mirabilis was prevalent and presented high resistance to tetracycline and chloramphenicol. Enterococcus isolates were vancomycin sensitive.
\end{abstract}

Key words: bacteria, conjunctiva, cataract, intraocular lens, antibiotic.

\section{INTRODUCTION}

Surgical removal of cataract (facectomy) is the most common eye surgery: in the United States, for example, over 1,000,000 patients are operated a year. Despite great progress has been made in surgical techniques, postoperative endophthalmia is one of the most feared complications of facectomy which may lead to total blindness in up to $50 \%$ of diagnosed cases $(19,27,35)$. However, some studies have reported bacterial contamination of the aqueous humour during cataract surgery, without occurring post-operative ocular infection $(3,37,43)$. Conjunctival endogenous microbiota is the main cause of postoperative and post-traumatic eye infections $(2,5,8)$. Molecular techniques have shown a great similarity among strains isolated from vitreous humour, eye anterior chamber and intraocular lens (IOL) in patients with Coagulase-negative staphylococci endophtalmia (17).
Gram-positive microorganisms may be found in up to $70 \%$ of endophthalmia cases, with coagulase-negative staphylococci (CNS) being the most common pathogens $(7,25,45)$. It is known that CNS are able to adhere and proliferate on polymeric surfaces, including IOL. Once adhered they secrete a viscous extracellular matrix (biofilm) which protects the microorganisms against the action of antibiotics and the host immune response $(12,14,42)$. When cultures were performed from swabs and lenses after contact with the conjunctiva of patients submitted to facectomy, the number of colonies isolated from IOL was four times higher than that obtained from swabs. This great difference was imputed to electrostatic charges that build up on the IOL metacrylate surface (44).

There is a deep concern with the increase of microbial resistance to drugs around the world. Several authors investigated the antimicrobial susceptibility of microorganisms isolated from ocular infection with different patterns of

*Corresponding author. Mailing address: Departamento de Microbiologia, Instituto de Ciências Básicas da Saúde, Universidade Federal do Rio Grande do Sul, Campus Central. Rua Sarmento Leite, 500. 90050-170, Porto Alegre, RS, Brasil. Tel.: (+5551) 3316-3445. E-mail: simonetti@cpovo.net. 
sensitivity occurring $(9,20,23,26,32,33)$, but little information is available in our country (25). The purpose of the present study was to evaluate the conjunctival aerobic microbiota of individuals submitted to cataract surgery and in vitro antimicrobial susceptibility of the isolates by using swabs and intraocular lenses for material collection.

\section{MATERIALS AND METHODS}

\section{Patients}

This procedure was carried out at Hospital de Clínicas da Universidade Federal do Rio Grande do Sul, RS, Brazil, from May to September 2000. Forty-six patients, from different geographical regions, submitted to facectomy followed by implantation of IOL through Brazilian National Health Service (SUS) were included.

\section{Intraocular lenses (IOL)}

Forty-six 6.5-mm PMMA IOL (MC50BD model, CILCO®, Alcon Surgical Inc., Forth Worth, Texas, USA), and forty-six 6mm silicon IOL (SSM26NB model, ALLERGAN MEDICAL OPTICS $^{\mathrm{TM}}$, Irvine, California, USA), whose straps were removed, were used in this study.

\section{Ocular material collection}

After agreement, collection of ocular material from the patient was carried out in two stages. The first one addressed identification of the endogenous microbiota including samples obtained during preoperative routine procedures. A moist sterile swab was smeared across the conjunctival sac, immediately placed in $2 \mathrm{~mL}$ brain-heart infusion (BHI) to send for analysis. The second step, before cataract surgery, was performed in the operating theatre where standard aseptic conditions were strictly observed. The eyelids, eyebrow, nose, cheek and forhead were scrubbed with $10 \%$ povidone-iodine in concentric rings outward from the eye. Then, one drop of 5\% povidon-iodine was instilled into the eye. One sterile silicon lens and one PMMA intraocular lens were used, for each patient, to collect the samples with help of sterile forceps. The IOL was touched onto the upper conjunctiva for 15 seconds, placed in a tube containing BHI and immediately transported to the laboratory for analysis.

\section{Isolation and microorganism identification}

The samples were incubated at $37^{\circ} \mathrm{C}$ for 18 to $24 \mathrm{~h}$, and then cultured onto $5 \%$ sheep blood agar, chocolate agar and MacConkey agar. Subsequently, samples were incubated at $37^{\circ} \mathrm{C}$ for 48 hours in microaerophilic environment (candle jar). Each morphologically distinct colony was Gram stained. Standard microbiological methods were used for microorganism identification as described below:

Gram positive cocci isolated on blood agar plates were identified by colonial morphology/hemolysis observation and the following tests: catalase, coagulase, oxidase, bacitracin and novobiocin susceptibility, manitol, $6.5 \% \mathrm{NaCl}$, bile esculin and optochin disk $(21,24)$.

The identification of Gram positive rods included esculin hydrolysis, arginine decarboxylation, carbohydrate fermentation (manitol, glucose, maltose, sucrose, trehalose, xylose, arabinose), Voges-Proskauer, urease, gelatin hydrolisis, catalase, SIM, nitrate reduction and Simmons citrate (22).

Gram negative rods were identified by tests of carbohydrate fermentation (glucose, manitol, lactose, maltose, trehalose), gas production, methyl red, Voges-Proskauer, urease, gelatin hydrolisis, oxidase, catalase, SIM, phenylalanine deaminase, nitrate reduction and Simmons citrate (22).

\section{Antimicrobial susceptibility testing}

Mueller-Hinton medium (ISOFAR, Rio de Janeiro, Brazil) was used to perform the diffusion test as established in the KirbyBauer method (4). The inoculum used in this assay corresponded to 0.5 in the MacFarland scale. The antibiotic discs tested (CEFAR, São Paulo, Brazil) included: chloramphenicol (30 $\mu \mathrm{g})$, ciprofloxacin $(5 \mu \mathrm{g})$, tetracycline $(30 \mu \mathrm{g})$, penicillin (10 UI), gentamicin $(10 \mu \mathrm{g})$, cephalothin $(30 \mu \mathrm{g})$, tobramycin $(10 \mu \mathrm{g})$, ofloxacin $(5 \mu \mathrm{g})$, kanamycin $(30 \mu \mathrm{g})$, vancomycin $(30 \mu \mathrm{g})$, and oxacillin $(1 \mu \mathrm{g})$. Results were interpreted after 18 to $24 \mathrm{~h}$ incubation, at $37^{\circ} \mathrm{C}$. Microorganisms were typed as sensitive (S), intermediately sensitive (I), or resistant (R) according to NCCLS (31).

Reference strains (ATCC 35984 S. epidermidis; ATCC 29213 S. aureus; ATCC 27853 P. aeruginosa) were used as a quality control for antimicrobials.

\section{RESULTS}

Out of 46 swabs used to assess the endogenous microbiota, bacterial growth was observed in 38 swabs (82.6\%), with 34 exhibiting pure cultures. In intraocular lenses, $16(34.8 \%)$ were positive for bacterial growth in PPMA lenses and 18 (39.1\%) for silicon lenses (Table 1).

Seventy six isolates and seven different microorganisms were identified as shown in Table 2. In swab samples $88 \%$ of

Table 1. Occurrence of positive and negative cultures in samples obtained from 46 patients using swab, polymethyl-metacrylate (PMMA) and silicon intraocular lenses (IOL).

\begin{tabular}{lccc}
\hline & $\begin{array}{c}\text { Positive } \\
\text { cultures }\end{array}$ & $\begin{array}{c}\text { Negative } \\
\text { cultures }\end{array}$ & Total \\
\hline Swab & $38(82,6 \%)^{1}$ & $08(17,4 \%)$ & 46 \\
PMMA LIO & $16(34,8 \%)$ & $30(65,2 \%)$ & 46 \\
Silicon LIO & $18(39,1 \%)$ & $28(60,9 \%)$ & 46 \\
\hline
\end{tabular}

${ }^{1}$ Mixed cultures occurred in four cases. 
Gram-positive microorganisms were detected: coagulasenegative staphylococci (CNS) in $71.4 \%$ of cases, followed by Staphylococcus aureus (9.5\%), Enterococcus spp. (4.8\%) and Corynebacterium pseudodiphteriticum (2.4\%). Gramnegatives were present in $12 \%$ of swab samples with the following microorganisms being isolated: Proteus mirabilis, Stenotrophomonas maltophilia and Acinetobacter calcoaceticus. In intraocular lenses Staphylococcus was isolated in most cases with predominance of CNS (81.3\% in PMMA and $77.8 \%$ in silicon lenses).

Table 3 shows the antimicrobial susceptibility level of CNS and $S$. aureus isolates. Among antibiotics tested the highest resistance was exhibited against penicillin $\mathrm{G}$ for both species,

Table 2. Bacteria species and respective frequency of isolates $(n=76)$ detected in ocular material from 46 patients using swab, polymethyl-metacrylate (PMMA) and silicon intraocular lenses (IOL).

\begin{tabular}{lccc}
\hline \multicolumn{1}{c}{ Bacteria Species } & Swab & $\begin{array}{c}\text { PMMA } \\
\text { IOL }\end{array}$ & $\begin{array}{c}\text { Silicon } \\
\text { IOL }\end{array}$ \\
\hline $\begin{array}{l}\text { Coagulase-negative } \\
\text { staphylococci }\end{array}$ & $30(71.4 \%)$ & $13(81.3 \%)$ & $14(77.8 \%)$ \\
$\begin{array}{l}\text { Staphylococcus } \\
\text { aureus }\end{array}$ & $4(9.5 \%)$ & $2(12.5 \%)$ & $2(11.1 \%)$ \\
$\begin{array}{l}\text { Enteroccus spp } \\
\text { Proteus mirabilis }\end{array}$ & $2(4.8 \%)$ & - & - \\
$\begin{array}{l}\text { Stenotrophomonas } \\
\text { maltophilia }\end{array}$ & $1(7.1 \%)$ & $1(6.2 \%)$ & $2(11.1 \%)$ \\
$\begin{array}{l}\text { Acinetobacter } \\
\text { calcoaceticus }\end{array}$ & $1(2.4 \%)$ & - & - \\
$\begin{array}{l}\text { Corynebacterium } \\
\text { pseudodiphteriticum }\end{array}$ & $1(2.4 \%)$ & - & - \\
\hline
\end{tabular}

Table 3. Antimicrobial susceptibility of coagulase-negative staphylococci and S.aureus isolates where $\mathrm{S}=$ sensitive, I= intermediate and $\mathrm{R}=$ resistant.

\begin{tabular}{|c|c|c|c|c|c|c|c|}
\hline \multirow[t]{2}{*}{ Antibiotic } & \multirow[t]{2}{*}{$\begin{array}{c}\text { Disc } \\
\text { concentration }\end{array}$} & \multicolumn{3}{|c|}{$\begin{array}{c}\text { Coagulase-negative } \\
\text { staphylococci }(n=57)\end{array}$} & \multicolumn{3}{|c|}{$\begin{array}{l}\text { Staphylococcus } \\
\text { aureus }(\mathrm{n}=8)\end{array}$} \\
\hline & & $\mathbf{S}$ & I & $\mathbf{R}$ & $\mathbf{S}$ & I & $\mathbf{R}$ \\
\hline Ciprofloxacin & $5 \mu \mathrm{g}$ & 46 & 04 & 07 & 04 & 04 & 0 \\
\hline Ofloxacin & $5 \mu \mathrm{g}$ & 52 & 02 & 03 & 08 & 0 & 0 \\
\hline Gentamicin & $10 \mu \mathrm{g}$ & 43 & 04 & 10 & 04 & 04 & 0 \\
\hline Tobramycin & $10 \mu \mathrm{g}$ & 44 & 06 & 07 & 05 & 03 & 0 \\
\hline Kanamycin & $30 \mu \mathrm{g}$ & 45 & 01 & 11 & 08 & 0 & 0 \\
\hline Cephalothin & $30 \mu \mathrm{g}$ & 53 & 02 & 02 & 08 & 0 & 0 \\
\hline Chloramphenicol & $130 \mu \mathrm{g}$ & 35 & 07 & 15 & 07 & 0 & 01 \\
\hline Tetracycline & $30 \mu \mathrm{g}$ & 35 & 02 & 20 & 08 & 0 & 0 \\
\hline Penicillin G & $10 \mathrm{IU}$ & 08 & 0 & 49 & 04 & 0 & 04 \\
\hline Oxacillin & $1 \mu \mathrm{g}$ & 51 & 01 & 05 & 08 & 0 & 0 \\
\hline Vancomycin & $30 \mu \mathrm{g}$ & 57 & 00 & 00 & 08 & 0 & 0 \\
\hline
\end{tabular}

as opposed to vancomycin, cephalothin and ofloxacin. All $S$. aureus isolates were sensitive to oxacillin and slight resistance was observed for CNS. Overall, some degree of resistance to aminoglycosides was detected for staphylococci. S. aureus isolates exhibited a better performance than CNS in relation to chloramphenicol and tetracycline.

Table 4 shows the antimicrobial activity of six P. mirabilis isolates. High level of resistance was observed to tetracycline and chloramphenicol. Considerable resistance occurred against aminoglycosides but all isolates were sensitive to ofloxacin and ciprofloxacin.

Enterococcus spp. isolates (2) were sensitive to vancomycin, as opposed to tetracycline (data not shown).

Table 4. Antimicrobial susceptibility of Proteus mirabilis isolates where $\mathrm{S}=$ sensitive, $\mathrm{I}=$ intermediate and $\mathrm{R}=$ resistant.

\begin{tabular}{lcccc}
\hline \multicolumn{1}{c}{ Antibiotic } & $\begin{array}{c}\text { Disc } \\
\text { Concentration }\end{array}$ & \multicolumn{3}{c}{$\begin{array}{c}\text { Proteus mirabilis } \\
(\mathrm{n}=6)\end{array}$} \\
\hline Ciprofloxacin & $5 \mu \mathrm{g}$ & 6 & 0 & 0 \\
\cline { 3 - 5 } Ofloxacin & $5 \mu \mathrm{g}$ & 6 & 0 & 0 \\
Gentamicin & $10 \mu \mathrm{g}$ & 3 & 2 & 1 \\
Tobramycin & $10 \mu \mathrm{g}$ & 3 & 2 & 1 \\
Kanamycin & $30 \mu \mathrm{g}$ & 0 & 6 & 0 \\
Cephalotin & $30 \mu \mathrm{g}$ & 3 & 2 & 1 \\
Chloram & $30 \mu \mathrm{g}$ & 0 & 4 & 2 \\
Tetracyclin & $30 \mu \mathrm{g}$ & 1 & 0 & 5 \\
\hline
\end{tabular}

\section{DISCUSSION}

Results shown in Table 1 reveal that samples collected using swab yielded a greater number of positive cultures when compared to those collected using intraocular lenses but slight differences were observed between silicon and PPMA lenses. This may be explained by the fact that swabs were used to sample the conjunctival sac preoperatively, differently from the procedure adopted to collect samples with intraocular lenses, carried out in the operating theatre, where sample collection followed aseptic care.

Another important aspect to be taken into consideration is that the bacterial population increases as on move away from the limbo into the palpebral margin. Marcon et al. (25) observed $45 \%$ of conjunctival positive cultures and $100 \%$ of positive cultures from samples collected from the palpebral margin. Interestingly, Speaker et al. (39) found that bacteria in the anterior chamber of the eye and those causing endophtalmia were identical in molecular terms to bacteria present in the bottom of the conjunctival sac and palpebral margin.

Staphylococcus epidermidis is a common microorganism found on skin and mucosae. As an opportunistic organism may 
contaminate medical devices such as intraocular lenses, leading to postoperative infections (endophtalmia) in patients who underwent cataract surgery (21). Doyle et al. (11) observed that $70 \%$ of the microorganisms present in the conjunctival flora in samples collected with swab were CNS, also detected in $82 \%$ of PMMA lenses after contacting the conjunctiva immediately following the surgical procedure. Mistlberger et al. (28) isolated $75 \%$ of CNS present in the conjunctival flora of aspirates collected from the eye anterior chamber. These data are very similar to ours that showed a $75 \%$ positivity for CNS. Hughes and Hill (15) reported that Gram-positive microorganisms may be found in up to $70 \%$ of the postoperative endophtalmia occurrences, with CNS being the most common one, present in about $40 \%$ of cases. $S$. aureus was found in $20 \%$ of cases, whereas Gram-negative microorganisms occurred in $16 \%$ of the cases. In isolates of ocular infections, Ooshi and Miyao (33) identified Gram-positive cocci in $44.7 \%$ of cases, with prevalence of CNS (52.6\% of cases) in contrast to $7.4 \%$ of Gram-negative bacilli $(7,4 \%)$.

In spite of the fact that the source of infection can not be determined in the majority of episodes after facectomy, microorganisms present in ocular normal flora and nearby structures are thought to be responsible for the infectious process $(7,25,39,40)$. It was reported that up to $20 \%$ of the bacteria present in this flora might be associated with biofilm formation and, once adhered by electrostatic attraction to the intraocular lens, will cause infection (29). When the conjunctival flora of patients submitted to facectomy was assessed prior to surgery, bacteria capable of causing endophtalmia were found in $74 \%$ of these individuals (45). On the other hand, it is well known that despite intense preoperative care of patients, either employing antibiotics or polyvinyl-pyrrolidone, the conjunctiva does not become refractory to bacterial growth $(2,5,6,8,16)$. We demonstrated in this study that it may be possible to occur contamination of IOL if they touch the conjunctiva, mainly by staphylococci.

Table 3 shows the antibiotic susceptibility of CNS and $S$. aureus. Vancomycin displayed the best activity, followed by cephalotin, ofloxacin and oxacillin. Higher resistance to aminoglicosides was detected in staphylococci isolates. Not surprisingly great resistance to penicillin $\mathrm{G}$ was observed. Kato and Hayasaka (20) detected 978 conjunctival isolates from 628 preoperative patients with no clinical eye infection: in 10 patients methicillin-resistant Staphylococcus aureus (MRSA) and methicillin-resistant staphylococci coagulase-negative (MRCNS) isolates were found to be sensitive to ofloxacin. Different authors examined the antibiotic susceptibility of bacteria isolated from ocular infection with MRSA accounting for $27 \%$ and MRCNS for $6.8 \%$ of strains. Most MRSA isolates were resistant to penicillin $\mathrm{G}$ and ofloxacin but sensitive to vancomycin (33). In our study, five methicillin-resistant CNS isolates $(8.8 \%)$ were found, but no methicillin-resistant $S$. aureus was isolated.
Fluoroquinolones for ophtalmic use include ciprofloxacin and ofloxacin. In general, ciprofloxacin has been showed to be more effective against the majority of microorganims that cause endophtalmia, though ofloxacin is able to penetrate more efficiently into ocular tissues $(9,23,32,38)$. Marone et al. (26) found high anti-staphylococci activity of ofloxacin against coagulase-negative staphylococci and $S$. aureus isolated from eye infections, which was also seen for tobramycin and gentamicin. In our study, better levels of acitivity were obtained with ofloxacin against CNS isolates (Table 3).

In relation to chloramphenicol and tetracycline, CNS exhibited greater resistance when compared to $S$. aureus, which was in turn susceptible to both antibiotics (Table 3). A study including 534 hemolytic staphylococci strains reported resistance to tetracycline in $13 \%$ and to chloramphenicol in $2 \%$ of occurrences (13). Petersdorf et al. (34) stressed a significant ability of staphylococci to develop resistance against chloramphenicol.

In our study, due to the low number of Enterococcus spp. and $C$. pseudodiphtheriticum isolates detected, the antibiotic susceptibility will not be discussed here.

Among Gram-negative microorganisms Proteus mirabilis predominated, exhibiting great susceptibility to ciprofloxacin and ofloxacin, resistance to tetracycline and intermediate sensitivity to kanamycin and chloramphenicol (Table 4). Ooshi and Miyao (33) observed that the majority of non-fermenter Gram-negative bacilli isolated in patients suffering from ocular infections was likewise susceptible to ofloxacin. Other studies confirmed in vitro $(10,26,36)$ and in vivo (23) efficiency of ciprofloxacin and ofloxacin against Gram-negatives including $P$. aeruginosa.

Overall, our study demonstrated that coagulase-negative staphylococci were the most commonly isolated aerobic microorganisms in ocular material, with predominance in samples collected with swab than in those collected with intraocular lenses. Among antimicrobials tested, the highest resistance was shown against Penicillin G, while vancomycin displayed the best activity, followed by cephalotin, ofloxacin and oxacillin. Additional studies are needed to evaluate the clinical importance of conjunctival endogenous microbiota on the pathogenesis of endophthalmitis and the influence of antibiotic resistance on treatment. In vitro experiments are underway in our laboratory to assess bacteria biofilm production an their interaction with PMMA and silicon intraocular lenses.

\section{ACKNOWLEDGEMENTS}

We thank Hospital de Clínicas de Porto Alegre where the patients were submitted to facectomy for implantation of intraocular lenses; CILCO Laboratories Alcon Surgical, Inc. (Fort Worth, Texas, USA) for providing the PMMA intraocular lenses; ALLERGAN MEDICAL OPTICS (Irvine, California, USA) for providing the silicon intraocular lenses; and $\mathrm{CNPq}$ for the financial support. 


\section{RESUMO}

\section{Microbiota endógena conjuntival em pacientes submetidos à cirurgia de catarata}

A partir de material ocular coletado de 46 pacientes submetidos à cirurgia de catarata foram realizados isolamento, identificação e teste de susceptibilidade de microrganismos frente a antimicrobianos, utilizando-se suabes e lentes intraoculares (LIO). Foram obtidos 76 isolados e identificados 7 tipos de microrganismos. Estafilococos coagulase-negativos (CNS) foram os microrganismos mais freqüentemente detectados de suabes (71,4\% dos casos), lentes de PMMA $(81,3 \%)$ e lentes de silicone $(77,8 \%)$. Isolados de CNS apresentaram elevada resistência à penicilina $\mathrm{G}$, seguida por tetraciclina, cloranfenicol e aminoglicosídeos. No entanto, estes isolados mostraram grande sensibilidade à vancomicina, cefalotina e ofloxacina. Com exceção da penicilina $\mathrm{G}$, os isolados de Staphylococcus aureus foram bastante sensíveis aos agentes antimicrobianos, incluindo a oxacilina. Entre as gramnegativas, Proteus mirabilis foi a bactéria mais frequiente e também se mostrou bastante resistente à tetraciclina e ao cloranfenicol. Os isolados de Enterococcus se mostraram sensíveis à vancomicina.

Palavras-chave: bactéria, conjuntiva, catarata, lente intraocular, antibióticos.

\section{REFERENCES}

1. Antunes, G.S. Manual de diagnóstico bacteriológico. Editora da Universidade. Universidade Federal do Rio Grande do Sul, Porto Alegre, 1995. 278p.

2. Apt, L.; Isenberg, S.J.; Yoshimori, R.; Chang, A; Lam, G.C.; Wachler, B.; Neumann, D. The effect of povidone-iodine solution applied at the conclusion of ophthalmic surgery. Am. J. Ophthalmol., 119:701705,1995

3. Aryasu, R.G.; Nakamura, T.; Trousdale, M.D.; Smith, R.E. Intraoperative bacterial contamination of the aquous humour. Ophthalmic Surg., 24:367-373, 1993.

4. Bauer, A.W.; Kirby, W.M.M.; Sherris, J.C.; Turck, M. Antibiotic susceptibility testing by a standardized single disk method. Am. J. Clin Pathol., 45:493-496, 1966.

5. Boes, D.A.; Lindquist, T.R.; Fritsche, T.R.; Kalina, R.E. Effects of povidone-iodine chemical preparation and saline irrigation on the perilimbal flora. Ophthalmology, 99:1569-1574, 1992.

6. Caldwell, D.R.; Kastl, P.R.; Cook, J.; Simon, J. Povidone-iodine: its efficacy as a preoperative conjunctival and perioperative preparation. Ann. Ophthalmol., 16:577-580, 1984.

7. Campos, M.S.Q.; Silva, L.Q.C.D.; Rehder, J.R.C.L.; Lee, M.B.; O'brien, T.; McDonnell, P.J. Anaerobic flora of the conjuntival sac in patients with AIDS and with anophtalmia compared with normal eyes. Acta Ophthalmol., 72:241-245, 1994.

8. Chitkara, D.K.; Manners, T.; Chapman, F.; Stoddart, M.G.; Hill, D.; Jenkins, D. Lack of effect of preoperative norfloxacin on bacterial contamination of anterior chamber aspirates after cataract surgery. Brit. J. Ophthalmol., 78:772-774, 1994.
9. Diamond, J.P.; White, L.; Leeming, J.P.; Hoh, H.B.; Easty, D.L. Topical $0.3 \%$ ciprofloxacin, norfloxacin, and ofloxacin in the treatment of bacterial keratitis: a new method for comparative evaluation of ocular drug penetration. Brit. J. Ophthalmol., 79:606609,1995

10. Dodds, M.G.; Grobe, K.J.; Stewart, P.S. Modeling biofilm antimicrobial resistance. Biotechnol. Bioeng., 68:456-465, 2000.

11. Doyle, A.; Beigi, B.; Early, A.; Blake, A.; Eustace, P.; Hone, R. Adherence of bacteria to intraocular lenses: a prospective study. Brit. J. Ophthalmol., 79:347-349, 1995.

12. Elder, M.J.; Stapleton, F.; Evans, E.; Dart, J.K.G. Biofilm-related infections in ophthalmology. Eye, 9:102-109, 1995.

13. Fischer, H.G. Die Häufigkeit penicillinresistenter staphylokokken. Dtsch. Med. Wschr., 84:257-258, 1959.

14. Griffiths, P.G.; Elliot, T.S.J.; McTaggart, L. Adherence of Coagulasenegative staphylococci to intraocular lenses. Brit. J. Ophthalmol., 73:402-406, 1989.

15. Hughes, D.S.; Hill, R.J. Infectious endophthalmitis after cataract surgery. Brit. J. Opthalmol., 78:227-232, 1994.

16. Isenberg, S.J.; Apt, L.; Yoshimori, R.; Khwarg, S. Chemical preparation of the eye in ophthalmic surgery. IV: comparison of povidoneiodine on the conjunctiva with a prophylactic antibiotic. Arch. Ophthalmol., 103:1340-1342, 1985.

17. Jansen, B.; Hartmann, C.; Schumacher-Perdreau, F.; Peters, G. Late onset endophthalmitis associated with intra-ocular lens: a case of molecularly proved Coagulase-negative staphylococci aetiology. Bri. J. Ophthalmol., 75:440-441, 1991.

18. Jones, D.; Collins, M.D. Irregular, nonsporing Gram-positive rods. In: Sneath, P.H.A.; Mair, N.S.; Sharpe, M.E. Bergey's manual of sistematic bacteriology. Willians \& Wilkins, 2:1261-1271, 1986.

19. Kanski, J.J. Clinical ophthalmology: sistematic approach. Heinemann International, Butterworth, 1994, 1236p.

20. Kato, T.; Hayasaka, S. Methicillin-resistant Staphylococcus aureus and methicillin-resistant coagulase-negative staphylococci from conjunctivas of preoperative patients. Jap. J. Ophthalmol., 42: 461-465, 1999.

21. Kloos, W.E.; Schleifer, K.H. Gram-positive cocci. In: Sneath, P.H.A.; Mair, N.S.; Sharpe, M.E. Bergey's manual of sistematic bacteriology. Willians \& Wilkins, 2:1015-1022, 1986.

22. MacFaddin, J.F. Biochemical tests for identification of medical bacteria. Lippincott Williams \& Wilkins, Philadelphia, 2000, 912 p.

23. Madaras-Kelly, K.J.; Larsson, A.J.; Rotschafer, J.C.A. Pharmacodynamic evaluation of ciprofloxacin and ofloxacin against two strains of Pseudomonas aeruginosa. J. Antimicrob. Chemother., 37:703-710, 1996.

24. Mahon, C.R.; Manuselis Jr., G. Diagnostic microbiology. W.B. Saunders Company, Philadelphia:, 2000. 1165p.

25. Marcon, A.S.; Barbosa, M.P; Vasques, C.L; Marcon, I.M.; Dorneles, I.C.; Kader, I.T.A.; Cauduro, P.F. Microbiota aeróbia e anaeróbia normal da conjuntiva e borda palpebral de indivíduos hígidos. Arq. Bras. Oftalmol., 59:289-294, 1996.

26. Marone, P.; Perversi, L.; Monzillo, V.; Maserati, R.; Antoniazzi, E. Ocular infections: antibiotics and bacterial adhesión on biomaterials used in ocular surgery. Ophthalmologica, 209:315-318, 1995.

27. Miller, K.M.; Glasgow, B.J. Bacterial endophthalmitis following sutureless cataract surgery. Arch. Ophthalmol., 111:377-379, 1993.

28. Mistlberger, A.; Ruckhofer, J.; Raithel, E.; Müller, M.; Alzner, E.; Egger, S.F.; Grabner, G. Anterior chamber contamination during cataract surgery with intraocular lens implantation. J. Cataract Refr. Surg., 23:1064-1069, 1997.

29. Miyanaga, Y.A. New perspective in ocular infection and the role of antibiotics. Ophthalmologica, 211(Suppl.1):b9-14, 1997.

30. Murray, P.R.; Baron, E.J.; Pfaller, M.A.; Tenover, F.C.; Yolken, R.H. Manual of clinical microbiology. ASM, Washington, 1999, 1773 p. 
31. National Committee For Clinical Laboratory Standards. Performance Standards for Antimicrobial Susceptibility Testing. (S.1.): NCCLS, Jan. 2000. Tenth informational supplement M100-S10 (M2).

32. Neu, H.C. Microbiologic aspects of fluoroquinolones. Am. J. Ophthalmol., 112(Suppl 1):15-24, 1991

33. Ooishi, M.; Miyao, M. Antibiotic sensitivity of recent clinical isolates from patients with ocular infections. Ophthalmologica, 211(Suppl. 1):15-24, 1997

34. Petersdorf, R.G.; Rose, M.C.; Minchew, H.B.; Keene, W.R.; Bennett, I.L.Jr. The sensitivity of hemolytic staphylococci to a series of antibiotics. Arch. Int. Med., 105:398-412, 1960.

35. Powe, N.R.; Schein, O.D.; Gieser, S.C; Tielsch, J.M; Luthra, R; Javitt, J.; Steinberg, E.P. Synthesis of the literature on visual acuity and complications following cataract extraction with intraocular lens implantation. Arch. Ophthalmol., 112:239-252, 1994.

36. Preston, C.A.K.; Khoury, A.E.; Reid, G.; Bruce, A.W.; Costerton, W. Pseudomonas aeruginosa biofilms are more susceptibile to ciprofloxacina than to tobramycin. Int. J. Antimicrob Ag., 7:251256, 1996.

37. Samad, A.; Solomon, L.D.; Miller, M.A.; Mendelson, J. Anterior chamber contamination after uncomplicated phacoemulsification and intraocular lens implantation. Am. J. Ophthalmol., 120:143$150,1995$.
38. Snyder-Perlmutter, L.S.; Katz, H.R.; Melia, M. Effect of topical ciprofloxacin $0.3 \%$ and ofloxacin $0.3 \%$ on the reduction of bacterial flora on the human conjunctiva. J. Cataract. Refr. Surg., 26:16201625,2000

39. Speaker, M.G.; Milch, F.A.; Shah, M.K.; Eisner, W.; Kreiswirth, B.N. Role of external bacterial flora in the pathogenesis of acute postoperative endophthalmitis. Ophthalmology, 98:639-650, 1991.

40. Stern, G.A.; Engel, H.M.; Driebe, W.T. Recurrent postoperative endophthalmitis. Cornea, 9:102-107, 1990.

41. Suter, L.S.; Ulrich, E.W. Routine bacterial sensitivity studies. Antibiot. Chemother, 9:38-46, 1959.

42. Townsend-Pico, W.A.; Meyers, S.M.; Langston, R.H.S.; Costin, J.A. Coagulase-negative Staphylococcus endophthalmitis after cataract surgery with intraocular vancomycin. Am. J. Ophthalmol., 21:318319, 1996.

43. Turkalj, J.W.; Carlson, A.N.; Manos, J.P.; Apple, D.J. Is the sutureless cataract incision a valve for bacterial inoculation? J. Cataract Refr. Surg., 21:472-476, 1995.

44. Vafidis, G.C.; Marsh, R.J.; Stacey, A.R. Bacterial contamination of intraocular lens surgery. Brit. J. Ophthalmol., 68:520-523, 1984.

45. Walker, C.B.; Claoué, C.M.P. Incidence of conjunctival colonization by bacteria capable of causing postoperative endophthalmitis. $J$. Roy. Soc. Med., 79:520-521, 1986. 


\section{TERMO DE CONSENTIMENTO}

A endoftalmite é uma infecção do olho que pode ocorrer em um de cada mil pacientes submetidos à cirurgia para extração da catarata. Esta doença é geralmente causada por bactérias e pode em alguns casos levar à perda total da visão no olho afetado.

Diversos estudos têm sido feitos nos últimos anos na tentativa de encontrar fatores que predisponham ao desenvolvimento desta doença. Isto tem permitido uma diminuição na incidência de endoftalmite, como a que se tem acompanhado década após década.

O Serviço de Oftalmologia do Hospital de Clínicas de Porto Alegre, através do seu corpo clínico, quer conduzir um estudo tentando identificar mais um possível fator de risco para esta doença.

Como você realizará cirurgia de catarata neste serviço, gostaríamos de convidá-lo a participar deste estudo como voluntário. A sua participação consiste em permitir que seja coletada amostra para exame bacteriológico antes da cirurgia, bem como no momento que esta ocorrer. A coleta das amostras será feita primeiramente com um suabe e após com uma lente intra-ocular. É importante ressaltar que a sua participação neste estudo não ocasionará nenhum risco adicional aos da própria cirurgia e será de grande importância para o avanço da ciência.

$\mathrm{Eu}$, fui claramente informado dos objetivos deste estudo e da metodologia empregada. Sei também que poderei retirar esse consentimento a qualquer momento se assim julgar adequado.

Assin. do(a) paciente

Assin. do(a) médico responsável

Assin. do orientador

Porto Alegre, de de 2000 